\title{
The 'Frontier' Speaks Back: Two Australian Artists Working in Paris and London
}

\author{
Catherine Speck, University of Adelaide
}

The two women artists who are the subject of this paper, Hilda Rix and Nora Heysen, worked from the 1900s to the 1940s in cosmopolitan Paris and London, at a time when it was almost obligatory to do so. This was part of the career pathway of any aspiring artist then, and as long-time ‘expatriate’ Geoffrey Batchen commented recently, 'Australians of ambition have always left to work and gain experience overseas. This is especially so for our better artists' (2007: 11). While that is so, it was Australian women artists in particular who circumvented a restrictive masculinism in local visual arts patronage, and headed overseas to develop their modern practice in this era. This expatriate group included not just Rix and Heysen, but Thea Proctor, Margaret Preston, Gladys Reynell, Dorrit Black, Grace Crowley and Anne Dangar, amongst others, and it is widely acknowledged that these women, in the main, ushered in modernism to Australia. This situation of women being the purveyors of modern style is a unique Australian phenomenon linked to travel, expatriatism and suffrage (Jordan 1994: 30).

Artists like Hilda Rix and Nora Heysen belonged to this cross-generational group of Australian women who travelled and immersed themselves in international modernism, an urban and metropolitan movement premised on the ideals of authenticity, autonomy and originality (Meesham \& Sheldon 2001: 1). International mobility defines engagement with this strand of modernism; hence the expatriate process of artists living outside their country of birth to complete their training, further their career or gain new experience was fundamental to their careers as modern artists. 
Expatriatism was a liberating period for women, especially women artists, and the strategies colonial women employed in living and working in metropolitan centres such as London have been explored in recent times (Woollacott 2001). However, the language used to describe it as fuelled by 'intellectual frustration' and 'alienation' from one’s country’ (Alomes 1999: 8); and as rather quaintly 'taking classes overseas’ as a prelude to doing the 'real' work done back home, has masked key features of time spent in the metropolis. The first is that insufficient attention has been given to the work artists produced elsewhere. In turn, the process by which artists working in the metropoles were transformed by this experience, has been insufficiently explored. Moreover, the language of expatriatism as a deliberate turning of one's back on country, rather than that of a dialectic process between home and away, has meant that the nature of modernism, as an international movement spread unevenly between the centres and peripheries, in which artists frequently moved from periphery to centre and back again, has been ill appreciated (Smith 2007: 7). Current transnational approaches to writing about artists and art histories are beginning to focus on the reality of this, and how artists from the mid-nineteenth-century operated in a more international ethos due to the 'growing infrastructure of international congresses, exhibitions and organisations' (Brockington 2009: 7). This paper probes how just two of these women artists from differing generations and in differing locales, Hilda Rix in Paris and Nora Heysen in London, tapped into this environment, and how their work changed. ${ }^{1}$

Once in metropolitan centres, both women artists immersed themselves in cosmopolitanism, an outlook and condition that rests in the social imaginary, and does not operate in opposition to or transcendence of nationalism (Calhoun 2008a: 433). Cosmopolitanism was a central tenet in turn-of-the-century modernism, and it was an early form of globalism involving 'the movement of objects, signs and people across regions and intercontinental spaces,' with 'patterns of reciprocal interaction' developing between those in the cultural centres and those coming to such centres (Held, McGrew, Goldblatt \& Perraton 1999: 328). What writers now refer to as a global consciousness was a feature of life then, due to transnational secular ideologies such as Marxism, liberalism and science, as well as international conflicts and new international communication systems (Cuddy-Keane 2003: 539-40). It constituted 'an outlook of cultural open-ness and receptivity to difference,' it signalled a 'direct connection

\footnotetext{
${ }^{1}$ Hilda Rix Nicholas worked in Paris as Hilda Rix: this was prior to her marriage.
} 
between the individual and the world as a whole' (Calhoun 2008a: 442), and it was facilitated by engaging in transnational networks with fellow cosmopolitans. This form of cosmopolitanism, grounded in modernism with its various inflections in centres and peripheries, has taken on a somewhat different usage in postcolonial discourse (Meskimmon 2011: 6-7, Calhoun 2008b: 105). ${ }^{2}$

Expatriate women artists in the modern era shifted in and out of this complex entity of cosmopolitanism. It was a role to be performed, what Amelia Jones and Andrew Stephenson describe as 'an aggressive resurfacing of the artist's persona through the enactment of her or his body in or as the work of art' (1999: 4). It was also a means of making contact, and enabling new forms of practice. Paris, as a major metropolitan centre, affected the making of art because artists working there from numerous nations had consciously moved away from all that was comfortable and familiar. These metropolitan influences played on Hilda Rix in Paris and Nora Heysen in London. Both found their identities in these two cities more fluid; they engaged with new styles and new subjects, and turned away from questions of their own nationality towards performative notions of hybrid individual identities. Their cosmopolitan experiences were almost incomprehensible to their peers who had stayed home and forged local inflections of modernism disembodied from metropolitan culture.

Hilda Rix was in Belle Époque Paris from 1907 to 1914, having moved there with her mother and sister where they soaked up cosmopolitan life. The city was a beacon to artists of differing nationalities and modern persuasions, Americans being the largest non-French contingent. Many academies were on offer, and artists’ studios were purpose-built for the foreign artists market, so expatriates transformed its art scene (Wilson 2002: 51). The Rix family lived in a pension at 7 rue Joseph Bara in fashionable Montparnasse, an area studded with artists’ studios and ateliers. Within a year Hilda Rix had taken classes at two of the most well-known Parisian art schools frequented by the large population of expatriate artists, Académie Delécluse in late 1907 and Académie de la Grande Chaumière in 1908.

The cosmopolitan ethos with which she was confronted, one of freedom and impulsiveness, initially unsettled her. Her restrictive colonial sensibilities caused her to

\footnotetext{
2 The contemporary usage of 'cosmopolitanism' extends these ideas across geographical, racial, national and religious borders and is infused with an ethics of responsibility within a world community.
} 
question her new-found autonomy, and she even wrote to a friend, 'one can do anything on wants in France. ${ }^{3}$ She was surrounded by a sophisticated and flamboyant lifestyle and during the pre-war years, a smart set thrived on its internationalism. They enjoyed the portraits of Sargent, the sculptures of Rodin, the music of Chopin, Schubert and Grieg, the dancing of Madame Sadayakko and the Ballets Russe, and they wore dresses by Worth and Paquin. Rix’s The pink scarf, 1913 [figure 1], which was painted in the latter part of her Paris years, is framed around these cosmopolitan sensibilities of

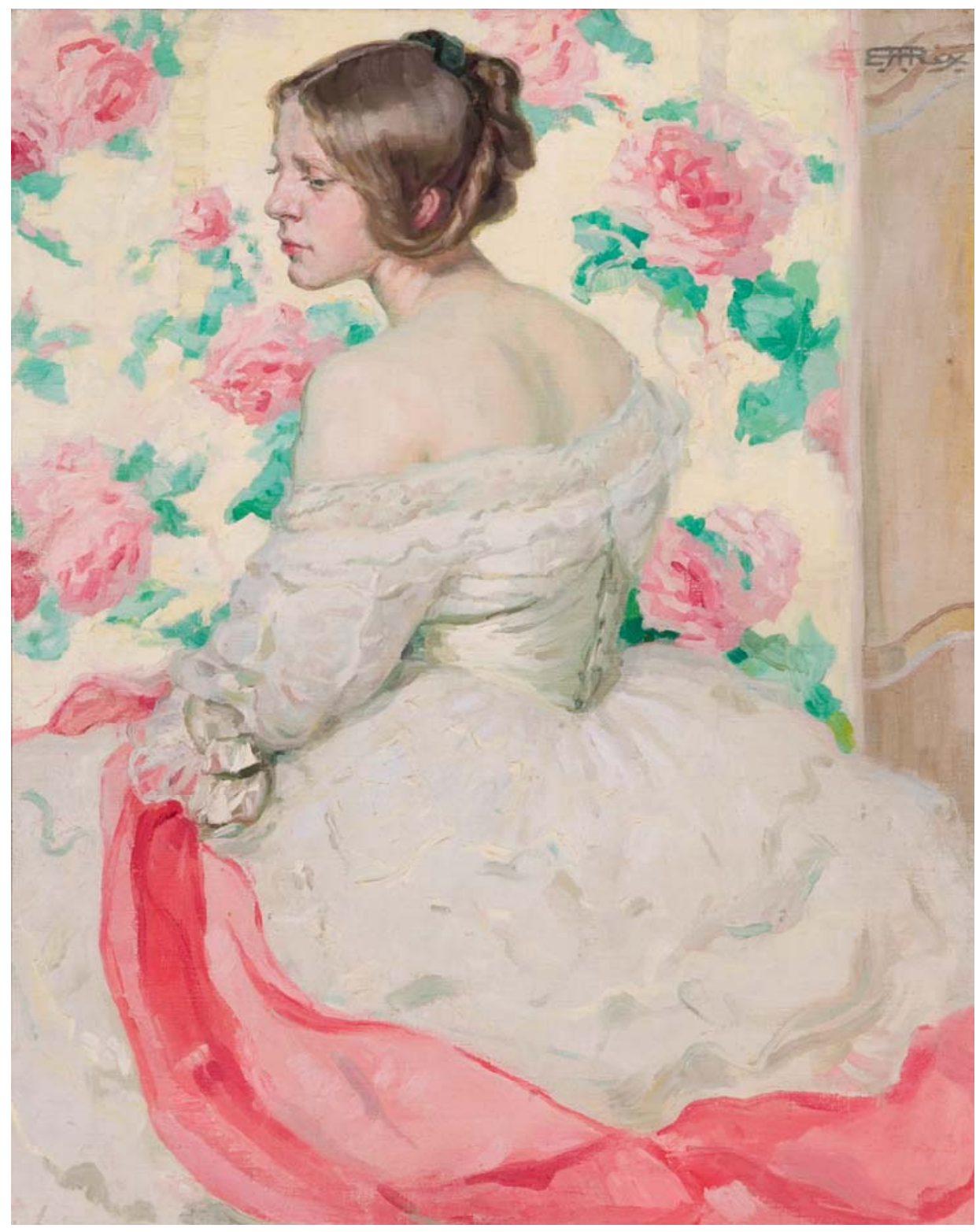

Figure 1, Hilda Rix Nicholas, The pink scarf, 1913, oil on canvas, 80.5 x $65.0 \mathrm{~cm}$, gift of Mrs Roy Edwards through the Art Gallery of South Australia Foundation 1993, Art Gallery of South Australia, Adelaide.

\footnotetext{
${ }^{3}$ Hilda Rix to Meg Line, 4 December 1907, Papers of Hilda Rix Nicholas, MS 9817, National Library of Australia. All subsequent letters cited from Hilda Rix are from this archive.
} 
pleasure, leisure and beautiful surfaces. Its subject, a fashionably dressed woman, is an overt display of the high life of Belle Époque Paris. It was painted when it was believed such portrayals would give pleasure to the general public (Galbally 2004: 120). The image is steeped in the Edwardian fascination with the reflective figure shown in interior domestic space. This is what Ann Galbally calls 'the subjectless subject,' in which the focus is on the figure, not as a psychological study but more 'as representative of a way of life' (2004: 118). Rupert Bunny, also an Australian expatriate artist in Belle Époque Paris, painted women in similar situations, but engaged in the high culture pursuits of listening to music or reading poetry within the domestic arena, whereas Rix’s woman is passive, posed, waiting, and contained. The filmy pink organza scarf trailing around the beautifully adorned young woman frames her, and accentuates her creamy off-the-shoulder gown. Her expansive uncovered back and shoulders are the focus of the gaze. The decorative flowery wallpaper screen behind her again creates a shallow space forcing the viewer's eyes onto the subject herself.

Rix had a fascination with fancy dress and masquerade, an interest which was part of a wider pre-war fascination with dress-up. Artists’ parties too were often fancy dress affairs or costume balls. ${ }^{4}$ Anne Gray suggests that 'artists wanted to show that art was artifice, a separate realm from reality. But they were keen also to show that the life of many around them was lived as a masquerade' (2004: 60). While steeped in these practices, Rix's sumptuous and highly coloured and patterned La robe Chinoise, c.1913 [figure 2], also drew on the fashion for non-western dress. Both Hilda and her sister Elsie enjoyed dressing up, Hilda even collected oriental costumes, but in a real sense wearing the dress of 'others' took what was then widespread cultural colonisation a step further to that of possession, and 'reinforced hierarchies of power' (Pigot 1994: 164). The model is Hilda's sister Elsie who projects a high sense of theatricality in her pose, as if she is self-consciously wearing an exotic gown, head-dress and jewellery. She prominently holds a bracelet and Chinese medallion for all to see. The bold outline around the gown further defines the figure against the shallow background. The dramatic lighting falls on the model's face and robe, while the pose shows every aspect of the gown to its utmost, harking back to what she learnt from Claudio Castelucho at the Académie de la Grande Chaumière. This painting was exhibited at both the Société des Artistes Français, and the Société des Peintres Orientalistes Français in 1914.

\footnotetext{
${ }^{4}$ When Rix returned from Europe she brought back costumes she had collected on her travels.
} 


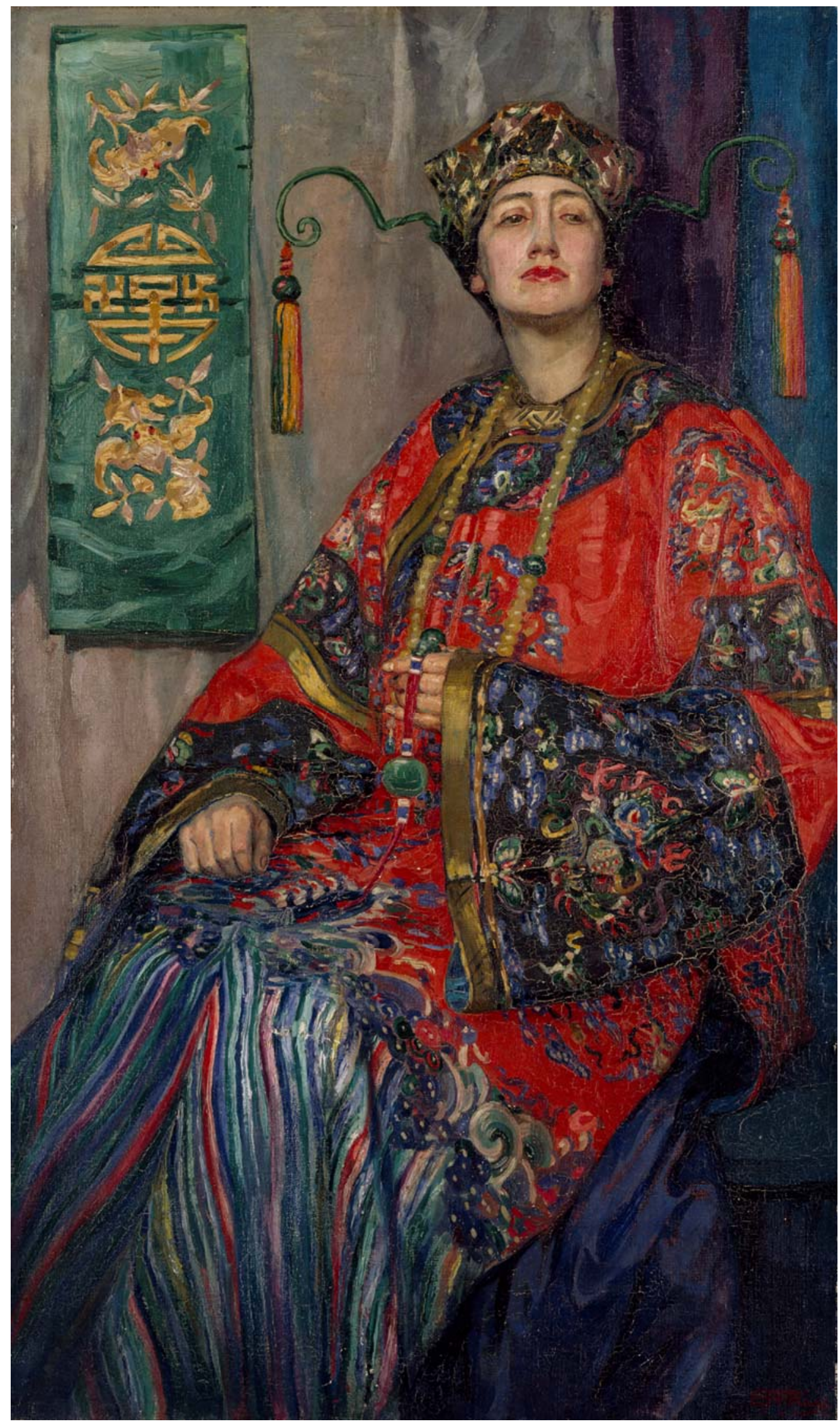

Figure 2, Hilda Rix Nicholas, La robe Chinoise, c.1913, oil on canvas, 185.3 x 115 cm, State Art Collection, Art Gallery of Western Australia, purchased through the Sir Claude Hotchin Art Foundation, Art Gallery of Western Australia Foundation, 1994. 
The artist's interest in the Orient was part of a larger fascination for 'the exotic,' which manifested itself in a French fashion for the Oriental imaginary as subject matter in art work. This in turn was underpinned by French colonialism in North Africa and the Middle East, and supported by a dedicated society of French Orientalist Painters, galleries and exhibitions. Thus while Orientalist art was shown unproblematically in Paris, it nonetheless brought 'the richness of colonised cultures to the attention of the metropolitan public' (Benjamin 2003: 62). These factors prompted Rix to travel to Morocco in 1912 and again in 1914. She made her first visit with African-American Henry Tanner, his wife and an extended group, and on the second occasion her sister Elsie accompanied her. The location inspired her to capture the light and atmosphere of life there. She also developed a great respect for the people whom she described as beautiful and dignified (Rix 1914: 41). Soon after arriving in Tangier she wrote to her friends that it was like being in dream: 'I'm afraid to wake up in the morning and find it all gone ... it is more splendid than I thought ... There is such quantity and richness of wonderful picturesqness; everyway one turns the head there is a new picture.' Rix sketched mostly in the market place, the Soko, adjacent to her hotel where some were happy to be portrayed, but others avoided the artist's gaze. This was a safe area for western woman to work in, and frequently the local people would gather around and watch her at work. Two women in the market place, 1912-1914 [figure 3], is typical of her work there. It is an impressionistic painting containing gestural features of the figures, with few details, and space is flattened and compressed. The high-keyed light shimmers. Rix studied the women carrying heavy loads on their backs, looking as she said like 'huge snails bent forward' (Rix 1914: 35). The women are diminutive in size but proud. The painting is a symphony in white light, and typifies John Pigot's observation: 'North Africa’s brilliant light transformed and modernised her work (2000: 26).

Rix's time in Paris had been a defining time. The liberties of Parisienne life shocked her at first. The 'cut-and-thrust' of working under the US modernist teacher Richard Miller, who was not always complimentary, meant she was always striving to improve. Her comment of his criticism — ‘if I'm successful with them won't I jump for joy'_implies many an occasion when she was not. Unfortunately her time in France was cut short by the declaration of war in 1914, and from their summer base in Étaples she and her family had to evacuate to Britain. Working in a cosmopolitan centre had transformed 


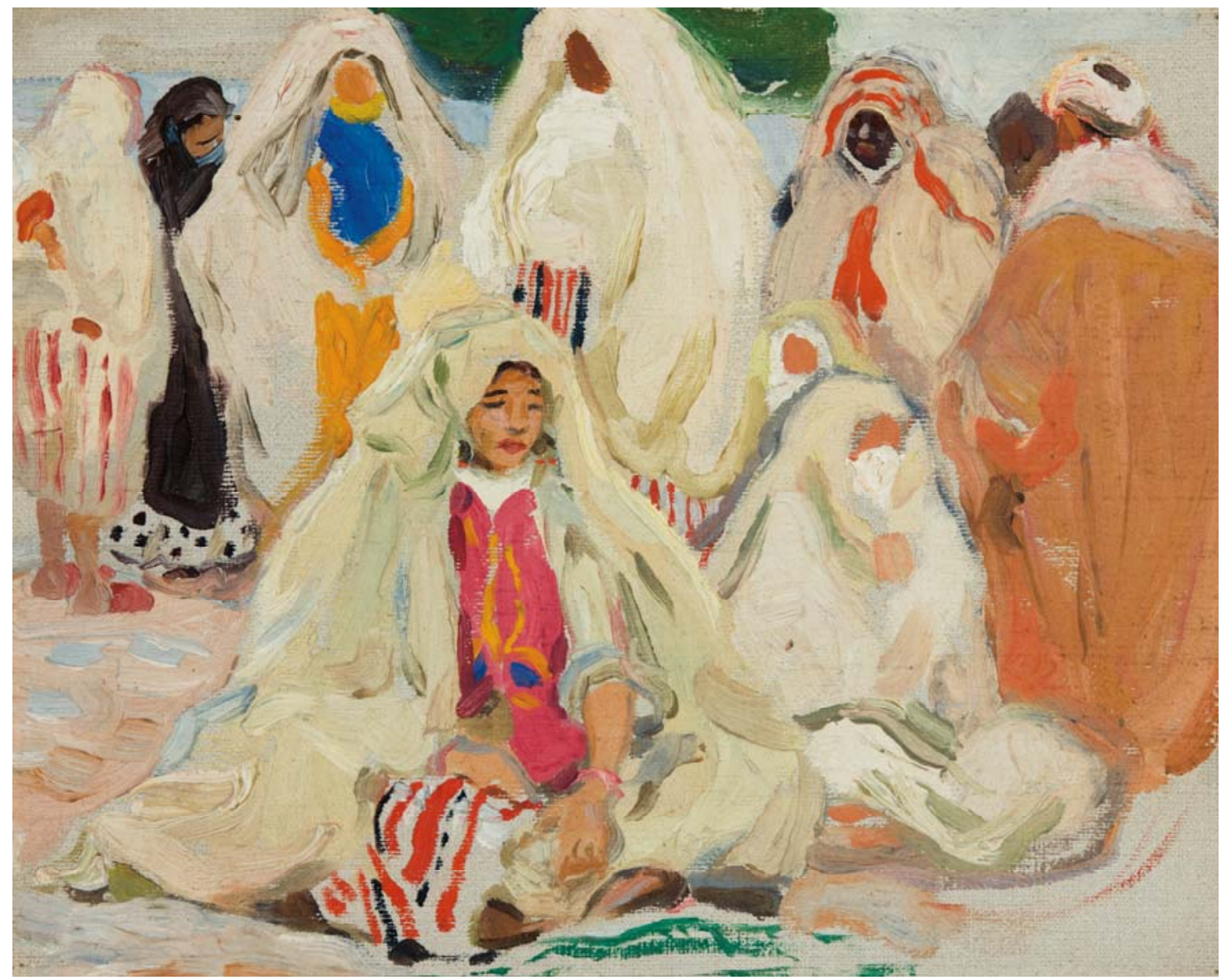

Figure 3, Hilda Rix Nicholas, Two women in the market place, c.1912-1914, oil on canvas on board, 25.8 x 32.5 cm, purchased 1994, Art Gallery of South Australia, Adelaide.

her practice, but we look to Raymond Williams to explain the exact nature of this change. He has observed that the 'complex and open character' of the major metropoles differed greatly from provincial areas where there was a 'persistence of traditional social, cultural and intellectual forms' (1992: 91). In his view the 'complexity' and 'miscellaneity' of this modern urban environment liberated artists and resulted directly in changes in form:

Thus the key cultural factor of the modernist shift is the character of the metropolis ... [and] its direct effect on form ... this underlies in an obvious way, the elements of strangeness and distance, indeed alienation, which so regularly form part of the repertory. But the decisive aesthetic effect is at a deeper level. Liberated or breaking from their national or provincial cultures, placed in quite new relations to those other native languages or native visual traditions, encountering meanwhile a novel and dynamic common environment from which many of the older forms were obviously distant, the artists and writers and thinkers of this phase found the only commonality available to them: a community of the medium; of their own practices. (Williams 1992: 91-92)

This same phenomenon of the liberating character of the city applied to London, even though the city itself was represented then as 'home' to Australians because it fell within the spatial imaginary of the British Empire (Blunt \& Dowling 2006: 143). Each 
of Paris and London provided this spark of creativity for cosmopolitan artists removed from provincial influences, with the only factor in common being their art practice. The consequent feelings of alienation, lack of belonging and, paradoxically, freedom from all ties saw artists making breakthroughs (Blazwick 2001: 9). These influences were highly conducive to their making of modern art. Those in the cosmopolitan centres found their identities more fluid, and they changed accordingly, and often radically. Artists there engaged with new styles and new subjects in universal or cosmopolitan spaces. They turned away from questions of their own nationality towards performative notions of hybrid individual identities. Hence, London, as the heart of the Empire, was only ever superficially familiar as 'home.' It operated at a deeper level as 'strange' and thus worked to liberate many artists, including the Australian Nora Heysen.

She was in London from 1934 to 1937, arriving when the worst years of depression has passed. Nora too worked in a cosmopolitan ethos, but one very different from Hilda Rix in the Belle Époque. Heysen set out to find her own painting style, self-funded by sales from a solo exhibition she held in Adelaide before leaving, and then from two loans from her father. Prior to relocating to Dukes Lane in Kensington in 1934, she had lived a very British-Australian life with her family at 'The Cedars' in Hahndorf. Her father, the well-known artist Hans Heysen, subscribed to papers like the Illustrated London News, corresponded with British artists, and recommended British works for acquisition by the Art Gallery of South Australia.

However, her transition to her new life in London was confronting, as her Self-portrait, 1934 [figure 4], painted a few months into her first year there, shows. This modern and visually arresting image of herself at 23 years of age feels like a statement made at the beginning of a journey, knowing she must be self-reliant and prove herself, but unsure what lies ahead. The brown jacket she is wearing underscores her aloneness; it seems to sit on her shoulders as if to suggest she is dressed in one of her few possessions, ready to confront the world.

This painting is about more than loneliness. It illustrates how the cosmopolitan experience not only required immersion in metropolitan culture, which in itself requires 'an outlook of ... cultural openness' (Calhoun 2008a: 442), but also that it involved listening to criticism. Heysen’s first teacher at London’s Central School, Bernard 


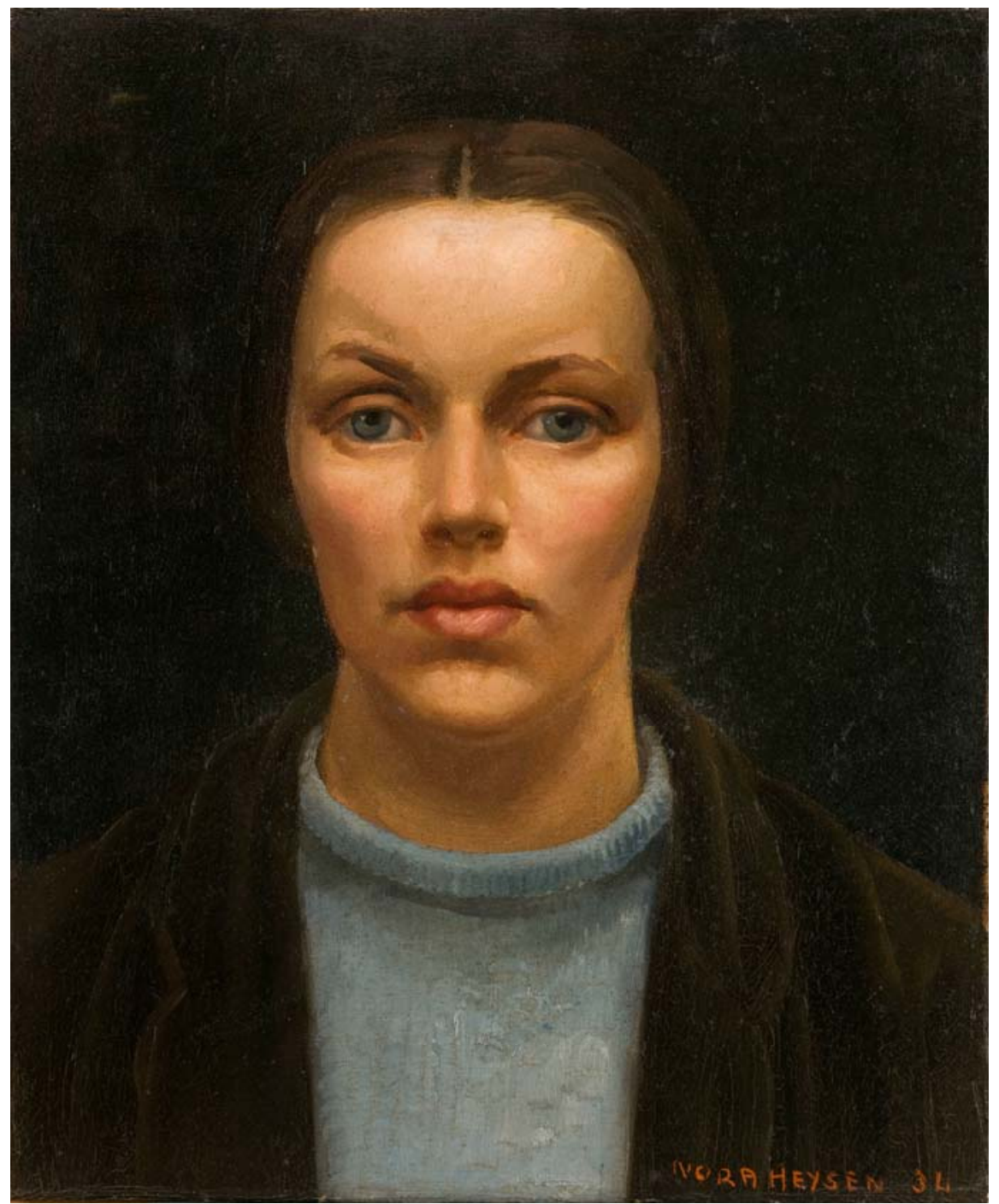

Figure 4, Nora Heysen, Self-portrait, 1934, oil on canvas, 60.8 x 53.5cm, purchased 1999, National Portrait Gallery.

Meninsky, was a highly respected modern artist who mixed with like-minded moderns including Jacob Epstein, Lucien Freud and the Bloomsbury group (Tickner 2000: 149). He told her that she had been taught incorrectly. His criticism struck at the core of her confidence, and caused her to question her father's tutelage. She described this incident as 'the worst most damning criticism I've ever had. ${ }^{5}$ His harsh criticism was due to the fact that each approached drawing from a different perspective. Meninsky, she said in a letter, 'draws with a heavy line and square modelling, handling the pencil like a pen, whereas I draw with a single line and use shading to emphasise certain forms.' Her style had underpinned earlier and more conventional self-portraits like her 1933 pre-London A portrait study, which had won her the South Australian Society of Arts Melrose Prize.

\footnotetext{
${ }^{5}$ Nora Heysen to her parents, 12 November 1934, Hans Heysen Papers, MS 5073, National Library of Australia. All subsequent letters cited from her are from this archive.
} 
Heysen was unsure whether to follow her own instincts or accept Meninsky’s advice. She wrote home that her dilemma was that 'he draws very well and I admire the solidity and movement he gets, but I don't want to draw like him.' She did, however, take on board some of his suggestions. The square modelling and sculptural solidity that were his trademark style carried over into her 1934 Self-portrait. Two weeks after Meninsky's criticism, she had come to terms with his comments-'I think I will gain from his criticism, it hurts no-one to be pulled to pieces and thoroughly faulted'-while again iterating her desire not to end up emulating his style. She was in a transitional space, open to new ways, but still in the process of finding herself having moved away from all that was familiar. As Iwona Blazwick comments, 'it is a paradox of the metropolis that its scale and heterogeneity can generate an experience both of unbearable invisibility and liberating anonymity; of alienating disconnectedness, indeed impotence; and of the possibility of unbounded creativity' (2001: 9).

Heysen was very aware of the opportunities working in London offered. She spent long hours drawing from the model at both art schools she attended, the Central School of Arts and Crafts and Byam Shaw. When not enrolled, she hired a model. She worked in still life, interiors and portraits, in each she was experimenting with light. By September 1935 she wrote home to her parents that she was now selecting modern frames for her paintings, a veiled way of letting them know she was changing: 'I'll wonder what you think of it. Probably think I'm going modern. I want things simple.'

Another major impetus to her art was meeting Orovida, daughter of Lucien Pissarro and grand-daughter of Camille Pissarro, ${ }^{6}$ whom she initially met in the course of arranging the purchase of Orovida's Mother and son for her father Hans Heysen in 1935. ${ }^{7}$ That financial transaction led to Orovida agreeing to look over Nora's work of which she was critical; she found it old fashioned. Nora wrote home to her father about Miss Pissarro’s comments in October 1935:

She came in like a bomb dropped out of the blue-She slated me right and left—-She said my paintings were muddy and 50 years behind time and advised me to change my palette-She admitted that I could draw and had talent but that is all she allowed me. She thinks I use too much brown and black and yellow ochre and keep my colour too low in tone-I who pride myself on my fresh bright clean colour! You can imagine my surprise on hearing that-She hates yellow ochre,

\footnotetext{
${ }^{6}$ Orovida felt burdened by her artistic lineage and ceased using her family name Pissarro and used her given name Orovida until the 1940s. By then her father had died.

${ }^{7}$ Hans Heysen was in London in 1934 and he saw this painting by Orovida at the 1934 Royal Academy exhibition, and decided to purchase it. He had an impressive art collection.
} 
and I love it and use it in everything almost - that is where we disagreed. She likes the interior I have just finished, and thought it the best bit of work-I agree there. She gave me a list of colours, an entirely new palette-mostly of cadmiums, excluding ochre, black and browns.

Heysen duly went out and purchased the new colours suggested of 'white, cadmium, red and pale ultramarine, vert composé, cobalt and crimson,' adding in her letter to her father, 'it is amazing the depth and richness of colour that can be got without using brown or black.' Those were the dark colours her father had taught her to use.

The consequent change in style from her new colours and approach is apparent in Heysen's self-portraits, which can be read as a coded language of defining herself as a modern artist and modern woman. To mark her twenty-fifth birthday and her transition to 'womanhood,' which she said had been hastened by 'living here by myself in London and making my own decisions,' she painted a Self-portrait, 1936. She wrote home 'I am doing myself in a blue smock against the wall with my pink roses—the colour scheme is beautiful and I hope to make something good out of it.’ Her use of paint is looser, with broken areas of colour in the face and in the background. Her palette, tipped forward for the viewer to inspect, shows her new colours on display. The subtext is that she has gone well beyond her early training. By February of that year, Heysen reported home that her new mentor Orovida was 'partly condemning, partly encouraging,' and that 'she likes the self-portrait, thinks it is far the best bit of painting I have ever done.'

She was moving from mimesis to a more expressive mode; and wrote home on Easter Sunday 1936 that she wanted to abandon what she called a photographic outlook:

I feel in sympathy with the impressionists who wanted to break away from all the old traditions, and find a new way to express beauty in nature. I feel I am getting nearer to that. I ultimately want losing a little of my hitherto rather photographic outlook, and getting more art and feeling into things. I feel freer and surer of myself, and know what I want.

In 1937 Heysen was soaking up the challenges of working in a metropolitan centre, and announced that she would not return to Australia until she could prove herself and find herself in London: 'I want to work out my life here ... I want to absorb as much as possible and experiment and learn.' She praised 'the education and stimulation' of living and working in a cosmopolitan city, and said that she wanted to exhibit there too. She had indeed come to terms with what Georg Simmel called metropolitan culture's 'patina of indifference,' resolving to rise above it (1902-1903). But like many an artist, five months later she had no money left and had to head back to Australia. Her last 
London self-portrait Down and out in London, 1937 [figure 5], alludes to her impoverished state, and shows her in modest domestic environs perched on the kitchen bench, the stove close by and laundry hanging behind her. The luscious greens of her clothing and the calm, relaxed pose imply that she has found her painting style; her hand resting on her palette points to the modern colours and areas of broken colour she has employed in her painting.

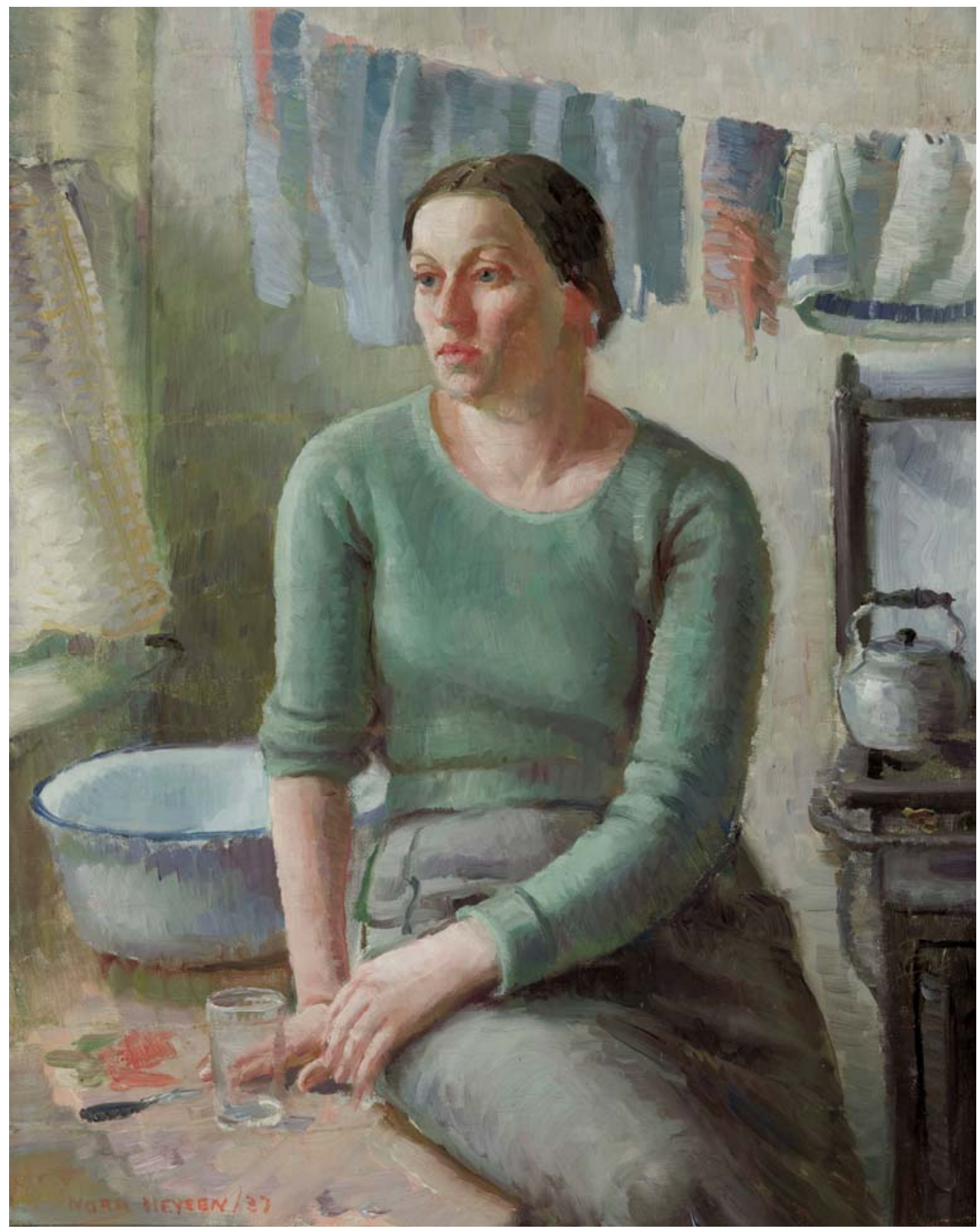

Figure 5, Nora Heysen, Down and out in London, 1937, oil on canvas, 55.0 x $40.0 \mathrm{~cm}$, South Australian Government Grant 1994, Art Gallery of South Australia, Adelaide.

Nora's work had changed, she had responded to the anonymity and fluidity of life in the metropolis, immersed herself in art and, in the process, confronted her own style. At 
times this was painful, as she wrote home in May 1936: 'It is funny in Australia I had a surfeit of praise, here I get nothing but adverse criticisms and jolts in all directions. Pity they couldn't be mixed a little more to even things out.'

She came back and painted a loose, confident and assertive Self-portrait in 1938 [figure 6]. By early 1939 she won the Archibald Prize for her portrait Madame Elink Schuurman; a goal she had set herself in London. Then in 1942 she won the Royal South Australian Society of Arts Melrose Prize for the second time for her painting

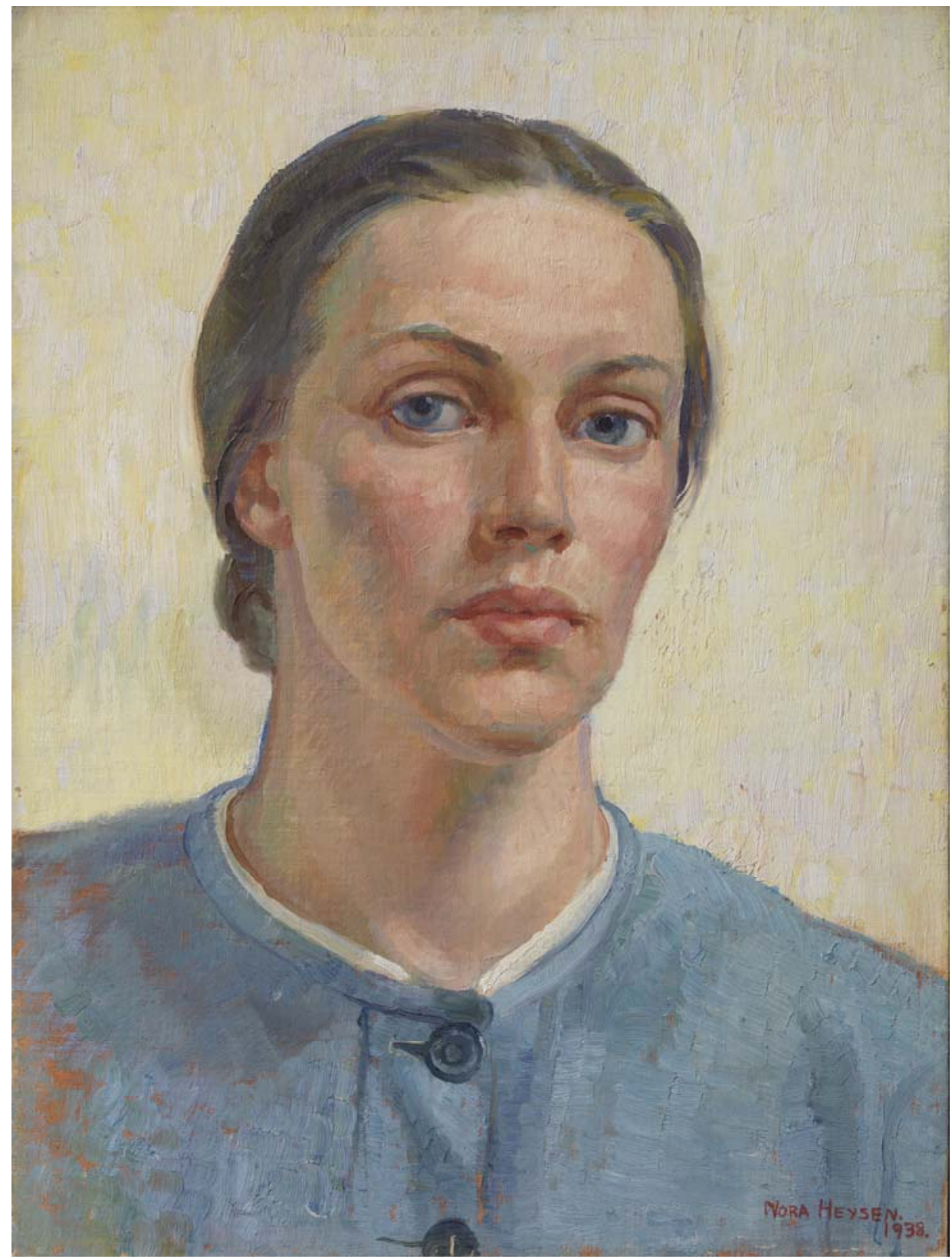

Figure 6, Nora Heysen, Self-portrait, 1938, oil on canvas laid on board, 39.5 x $29.5 \mathrm{~cm}$, purchased 2011 with funds from Philip Bacon, AM, through the Queensland Art Gallery Foundation, Queensland Art Gallery @ Lou Klepac. 
Motherhood. In 1943 she was appointed as an official war artist. None of that would have occurred without the impetus of the liberating cosmopolitan experience in London.

Hilda Rix's world, on the other hand, had been turned upside down by events of the First World War. When she returned to Australia in late June 1918, she was a war widow. She married Major George Matson Nicholas in 1916 in London, but he died near the battlefield five weeks later. While overseas, she also lost her sister from enteric fever, then her mother; and came close to personal despair. However, she brought back an extraordinary cache of paintings and drawings which, when shown in Melbourne and Sydney, were extremely well received by the critics. The Age critic commented on 12 November 1918 on 'the influence of modern French impressionism in their fearless handling of sunlight.' On the same day, the Argus noted her 'high accomplishment in colour and composition,' while the Sydney Morning Herald observed on 11 June 1919 that 'her style is forcible and direct, her figures were full of character, her drawing virile in it certainty and boldness of effect.' Her Paris work became her high water mark. Feeling obliged to honour the memory of her late husband, her work thereafter pursued a more national agenda, and was uneven.

The key impetus to change in Rix Nicholas’s Paris work and Heysen’s London work was the character of the metropolis, the alienation and cultural dislocation it initially produced, and how each artist responded with cosmopolitan openness to new ways. Like Raymond Williams, Angela Woollacott points to how the emotions of strangeness and alienation associated with migration to the metropolis are central to the emergence of cultural modernism in the work of expatriate women. In her view (2001: 212), women artists from the colonies who embraced cosmopolitanism contributed significantly to metropolitan culture. But it was much more than that. Rix Nicholas and Heysen each brought back from 'the frontier' modern work that was testament to their time away. Travel, and living and working in the metropolis had facilitated artistic shifts of style, but for each a world war intervened. Following the First World War, Rix Nicholas though was back in Paris from 1924-1927, and after the Second World War, Heysen was back in Britain: Liverpool then London in 1948. Each was between nations, enriched and transformed by working at the 'frontiers' of modernism, their art produced there integral to Australian modernism. 


\section{Reference List}

Alomes, S. 1999, When London Calls: The Expatriatism of Australian Creative Artists to Britain. Cambridge University Press, Cambridge.

‘Art Exhibition’ 1918, Age, 12 November.

Batchen, G. 2007, 'From Elsewhere,' in Love it and Leave It, (ed.) N. Latham. National Portrait Gallery, Canberra.

Benjamin, R. 2003, Orientialist Aesthetics: Art, Colonialism and French North Africa 1880-1930. University of California Press, Berkeley.

Blazwick, 1. 2001, 'Century City,' in Century City: Art and Culture in the Modern Metropolis, (ed.) I. Blazwick. Tate Modern, London: 8-15.

Blunt, A. and Dowling, R., Home. Routledge, London, 2006.

Brockington, G. 2009, 'Introduction: Internationalism and the Arts' in Internationalism and the Arts in Britain and Europe at the Fin de Siecle, (ed.) G. Brockington. Peter Lang, Bern: 1-26.

Calhoun, C. 2008a, 'Cosmopolitanism and Nationalism,' Nations and Nationalism, vol. 14, no. 3: 427-48. 2008b, 'Cosmopolitanism in the Social Imaginary,' Daedalus, no. 3: 105-14.

Cuddy-Keane, M. 'Modernism, Geopolitics, Globalisation,’ Modernism/Modernity, vol. 10, no. 3: 53958.

Galbally, A. 2004, 'Reflected Selves: Australian Expatriate Artists in an Edwardian World,' in The Edwardians: Secrets and Desires. National Gallery of Australia, Canberra.

Gray, A. 2004, 'The Edwardians,' in The Edwardians: Secrets and Desires. National Gallery of Australia, Canberra.

Hans Heysen Papers, MS 5073, National Library of Australia.

Held, D., McGrew, A., Goldblatt, D. \& Perraton, J. 1999, Global Transformations: Politics, Economics and Culture. Polity Press, Cambridge.

Jones, A. and Stephenson, A. 1999, 'Introduction,' in Performing the Body/Performing the Text, (eds) A. Jones \& A. Stephenson. Routledge, London: 1-10.

Jordan, C. 1994, 'Designing Women: Modernism and its Representation in Art in Australia,' in Strange Women: Essays in Art and Gender (ed.) J. Hoorn. Melbourne University Press, Carlton: 28-37.

Meecham, P. and Julie Sheldon, 2001, J. Modern Art: A Critical Introduction. Routledge, London.

Meskimmon, M. 2011, Contemporary Art and the Cosmopolitan Imagination. Routledge, Oxon.

Papers of Hilda Rix Nicholas, MS 9817, National Library of Australia.

Pigot, J. 1993, Capturing the Orient: Hilda Rix Nicholas and Ethel Carrick in the East. Waverley City Gallery, Victoria. 1994, 'Les Femmes Orientalistes: Hilda Rix Nicholas and Ethel Carrick in the East,' in Strange Women: Essays in Art and Gender, (ed.) J. Hoorn. Melbourne University Press, Carlton: 155-68.

Pigot, J. 2000, Hilda Rix Nicholas: Her Life an Art. Mieugunyah Press, Melbourne.

'Rix Nicholas: Australian Artist’s Return: Notable Successes Abroad’ 1919, Sydney Morning Herald, 11 June.

Rix, H. 1914, 'Sketching in Morocco,' The Studio, vol. 63: 35-41.

Smith, B. 2007, The Formalesque: A Guide to Modern Art and its History. Macmillan, South Yarra.

Tickner, L. 2000, Modern Life and Modern Subjects: British Art in the Early Twentieth Century. Yale University Press, New Haven.

Williams, R. 1992, 'The Metropolis and the Emergence of Modernism,' in Modernism/Postmodernism (ed.) P. Brooker. Longman, London: 82-94.

Wilson, S. 2002, Paris: Capital of the Arts 1900-1968, Royal Academy of the Arts, London.

'Work of Mrs Rix Nicholas: Paintings of Distinction' 1918, Argus, 12 November.

Woollacott, A. 2001, To Try Her Fortune in London. Oxford University Press, Oxford. 